\title{
PENGARUH KEDISIPLINAN LOYALITAS DAN KEPEMIMPINAN TERHADAP PRODUKTIVITAS KERJA PADA SEKRETARIAT DEWAN PERWAKILAN RAKYAT DAERAH KABUPATEN KEPULAUAN SELAYAR
}

\author{
Agustini*1, Syamsul Alam², Andi Djalante $^{3}$ \\ ${ }^{* 1}$ Program Pascasarjana Magister manajemen, STIE Nobel Indonesia Makassar \\ e-mail: agustinisapa@gmail.com , syamsulalam@stienobel-indonesia.ac.id, djalante@gmail.com
}

\begin{abstract}
Abstrak
Penelitian ini bertujuan untuk menganalisis apakah ada pengaruh antara Kedisiplinan, Loyalitas dan Kepemimpinan terhadap Produktivitas Kerja Pada kantor Sekretariat Dewan Perwakilan Rakyat Daerah kabupaten kepulauan Selayar Metode yang digunakan adalah metode deskriptif kuantitatif, data yang digunakan adalah data primer dan data sekunder yang dihasilkan dari penyebaran kuisioner, observasi langsung dan studi kepustakaan. Alat analisis yang digunakan adalah analisa statistika yaitu analisa regresi linier berganda dengan pembuktian hipotesis melalui uji t untuk membuktikan keterkaitan antara variabel independent dengan variabel dependent secara parsial dan uji f untuk membuktikan keterkaitan antara variabel independen dengan variabel dependent secara simultan. Penelitian dilakukan dengan mengambil sampel sebanyak 88 responden yang merupakan jumlah seluruh Pegawai pada Kantor Sekretariat Dewan Perwakilan Rakyat Daerah Kabupaten Kepulauan Selayar. Penelitian ini membuktikan terdapat pengaruh yang positif tapi tidak signifikan antara variabel Kedisiplinan dan Loyalitas terhadap Produktivitas Kerja serta terdapat pengaruh yang positif dan signifikan antara variabel Kepemimpinan Terhadap Produktivitas Kerja Pada Sekretariat Dewan Perwakilan Rakyat Daerah Kabupaten Kepulauan Selayar. Penelitian ini juga membuktikan bahwa terdapat pengaruh yang positif dan signifikan antara variabel Kedisiplinan, Loyalitas dan Kepemimpinan secara bersamasama (simultan) terhadap Produktivitas Kerja Pada Sekretariat Dewan Perwakilan Rakyat Daerah Kabupaten Kepulauan Selayar. Penelitian ini juga menunjukan bahwa variable Kepemimpinan merupakan variabel yang paling dominan mempengaruhi Produktivitas Kerja pada Sekretariat Dewan Perwakilan Rakyat Daerah Kabupaten Kepulauan Selayar.
\end{abstract}

Kata kunci : Kedisiplinan, Loyalitas, Kepemimpinan, dan Produktivitas

\begin{abstract}
This study aims to analyze whether there is an influence between Discipline, Loyalty and Leadership on Work Productivity at the Secretariat of the Regional People's Representative Council, Selayar Islands. The method used is descriptive quantitative method, the data used are primary data and secondary data generated from distributing questionnaires, direct observation and literature study. The analytical tool used is statistical analysis, namely multiple linear regression analysis with proof of the hypothesis through the t test to prove the relationship between the independent variable and the dependent variable partially and the f test to prove the relationship between the independent variable and the dependent variable simultaneously. The study was conducted by taking a sample of 88 respondents, which is the total number of employees at the Secretariat of the Regional People's Representative Council of the Selayar Islands Regency. This study proves that there is a positive but insignificant influence between the Discipline and Loyalty variables on Work Productivity and there is a positive and significant influence between the Leadership variable on Work Productivity at the Regional Representative Council Secretariat of the Selayar Islands Regency. This study also proves that there is a positive and significant influence between the variables of Discipline, Loyalty and Leadership simultaneously
\end{abstract}




\section{AkMen \\ Volume 17 Nomor 3 September 2020 \\ Hal. 427 - 437 \\ e-ISSN : 2621-4377 \& p-ISSN : 1829-8524 \\ Hbmepage: https//e-jumal.stienobel-indonesia.acid/index.php/akmen}

(simultaneously) on Work Productivity at the Secretariat of the Regional People's Representative Council of the Selayar Islands Regency. This study also shows that the leadership variable is the most dominant variable affecting Work Productivity at the Regional Representative Council Secretariat of the Selayar Islands Regency.

Keywords : Discipline, Loyalty, Leadership, and Productivity

\section{PENDAHULUAN}

Organisasi tidak bisa dilepaskan dari faktor manusia sebagai penggerak dari organisasi itu sendiri sehingga pengelolaan sumber daya manusia menjadi sangat penting ibarat tubuh sesungguhnya manajemen sumber daya manusia adalah jantung dari organisasi sebagai pelaku utama dalam kegiatan operasional organisasi. Oleh sebab itu pula perilaku pegawai sebaiknya dapat diarahkan untuk memiliki kemampuan dalam mendukung tujuan organisasi. Perilaku pegawai pada dasarnya menyangkut berbagai kegiatan di dalam organisasi karena perilaku merupakan cerminan keterlibatan serta keberadaan pegawai dalam sebuah organisasi, dan karena itu menjadi sangat penting bagi organisasi untuk dapat mengelola keperilakuan tersebut menjadi sebuah kemampuan yang bermakna positif terutama dikaitkan dengan maksud dan tujuan organisasi.

Dalam praktek pengelolaan sumber daya manusia, ada sejumlah aspek dapat diidentifikasi sebagai upaya perbaikan dan penyempurnaan pengelolaan organisasi khususnya didalam peningkatan produktivitas kerja organisasi diantaranya adalah kedisiplinan, loyalitas, komitmen pegawai, rasa memiliki, tanggung jawab, kepemimpinan dan permasalahan engagement (Rivai, 2004). Pada dasarnya manusia adalah pemimpin bagi dirinya sendiri dan dalam perkembangannya seseorang dapat tumbuh dan berkembang dan dapat menjadi pemimpin bagi orang lain. Sebagai seorang pemimpin maka ia akan dapat menginspirasi dirinya maupun orang lain dalam pencapain kualitas kerja dan juga prestasi kerja. Pemimpin yang efektif akan mampu mengorganisir dan membantu orang atau kelompok dalam mencapai tujuan. Sifat kepemimpinan harus dimiliki oleh setiap orang dengan sifat kepemimpinan tersebut seseorang akan memiliki keyakinan terhadap dirinya sendiri untuk mampu dengan baik melakukan segala tanggungjawab tugas dan kewajibannya bahkan dalam kesempatan yang lain sifat kepemimpinan tersebut akan menginspirasi orang lain untuk melakukan suatu hal yang terbaik dan mencapai tujuan yang diinginkan begitu pentingnya kepemimpinan dalam organisasi maka konsep pengembangan Human Capital Management menempatkan kepemimpinan sebagai salah satu factor yang diperhitngkan dalam pengembangan konsep tersebut. (Hidayat, M., \& Latief, F., 2018).

Sifat-sifat kepemimpinan tersebut juga seharusnya dimiliki oleh setiap pegawai tidak terkecuali pegawai pada Sekretariat DPRD Kabupaten Kepulauan Selayar. Penulis merasa terpanggil untuk melakukan penelitian terkait dengan sifat kepemimpinan pegawai karena sifat-sifat kepemimpinan itu penting apalagi paradigma masyarakat yang melihat Kantor Sekretariat DPRD adalah kantor wakil rakyat di mana para pegawai juga harus mencerminkan sebagai pegawai yang memiliki kepekaan tinggi terkait dengan permasalahan sosial politik dan kemasyarakatan pengamatan yang telah penulis lakukan terkait dengan sifat kepemimpinan ini masih dirasa perlu untuk ditingkatkan. Fenomena yang terjadi saat ini para pegawai sekretariat sering bekerja dibawah bayangbayang para wakil rakyat sehingga cenderung untuk melakukan saja apa yang diminta 


\section{AkMen}

Volume 17 Nomor 3 September 2020

Hal. 427 - 437

e-ISSN : 2621-4377 \& p-ISSN : 1829-8524

Hbmepage: https//e-jumal.stienobel-indonesia.acid/index.php/akmen

oleh para wakil rakyat tersebut. Hal ini menjadi fenomena menarik karena bekerja dalam bayang bayang akan menjadi preseden buruk jika tidak dimanaj dengan baik dan benar.

Sifat kepemimpinan yang positif pada akhirnya akan mendorong seorang pegawai untuk dapat melakukan pekerjaan yang menjadi kewenangan dan tanggungjawabnya dengan baik dan benar dan tak dapat dipungkiri hal tersebut diyakini akan dapat menjadi pemacu timbulnya produktivitas bagi pegawai yang bersangkutan.

Berdasar pada uraian diatas maka penelitian ini disusun melalui konsep kerangka pemikiran yang dapat digambarkan sebagi berikut :

Gambar 1. Kerangka Konsep Penelitian

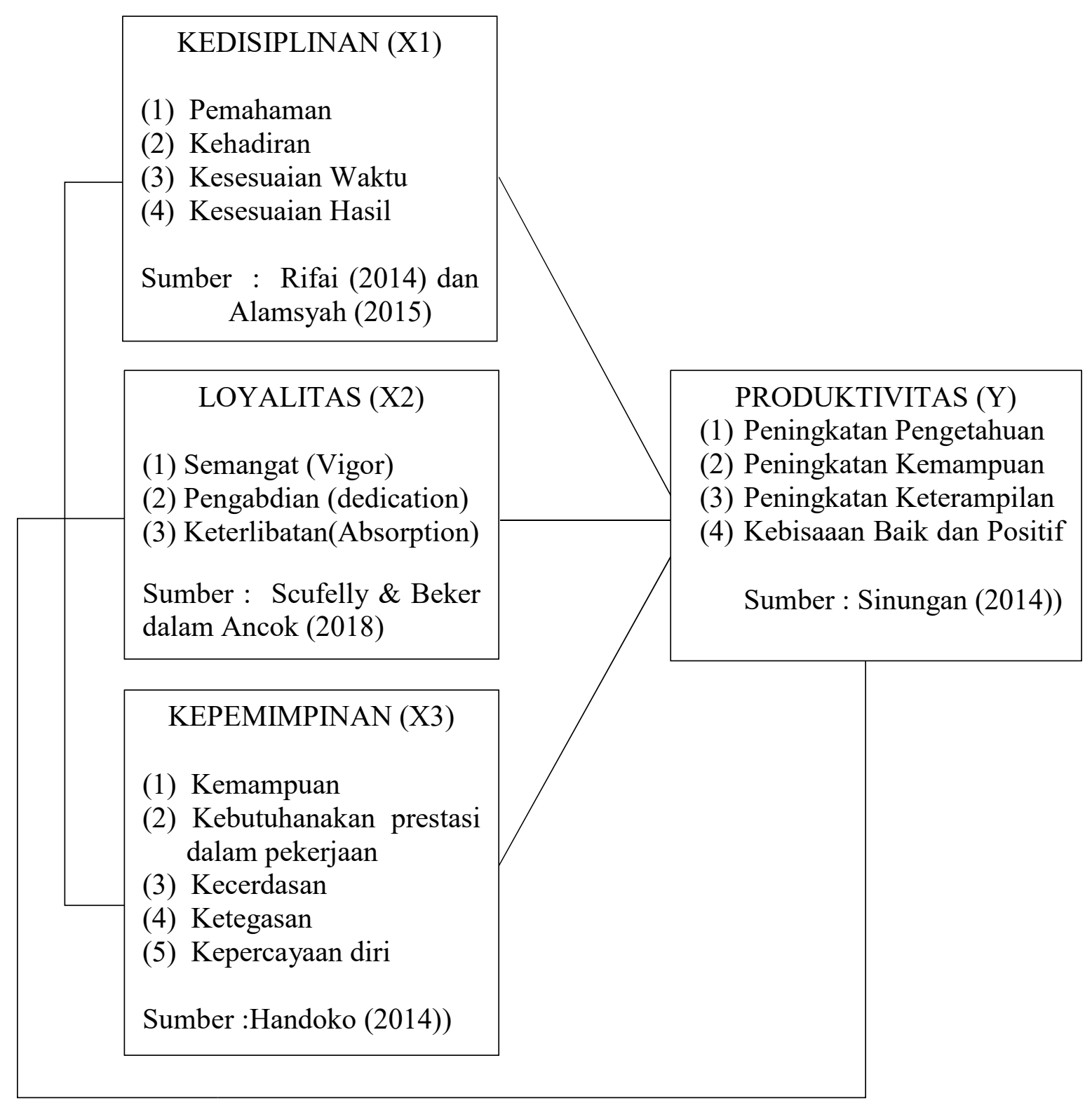

METODE PENELITIAN

Penelitian ini adalah penelitian deskriptif analistis dengan menggunakan pendekatan analisis kuantitatif. Metode deskriptif adalah suatu metode yang bertujuan 
untuk mendeskripsikan atau menggambarkan obyek penelitian secara sistematis faktual dan akurat mengenai fakta-fakta serta hubungan-hubungan antara variabel yang dijadikan sebagai variabel penelitian.

Pendekatan kuantitatif adalah suatu pendekatan yang digunakan dalam penelitian melalui perhitungan-perhitungan matematis untuk membuktikan secara ilmiah apakah ada hubungan-hubungan yang terjadi diantara variabel penelitian dan sejauh mana implikasinya terhadap variabel tertentu yang ingin dibuktikan dalam penelitian ini.

\section{HASIL PENELITIAN DAN PEMBAHASAN}

Hasil

Analisis regresi linier berganda digunakan dalam penelitian ini dengan tujuan untuk membuktikan hipotesis mengenai pengaruh variable kedisiplinan, loyalitas dan kepemimpinan secara parsial maupun secara bersama-sama terhadap produktivitas Pegawai Sekretariat Dewan Perwakilan Rakyat Daerah Kabupaten Kepulauan Selayar. Perhitungan statistic dalam analisis regresi linier berganda yang digunakan dalam penelitian ini adalah dengan menggunakan bantuan program komputer IBM SPSS for Windows versi 25. Hasil pengolahan data dengan menggunakan program SPSS selengkapnya ada pada lampiran dan selanjutnya dijelaskan pada Tabel 1 berikut ini :

Tabel 1 Hasil Analisis Regresi Linier Berganda

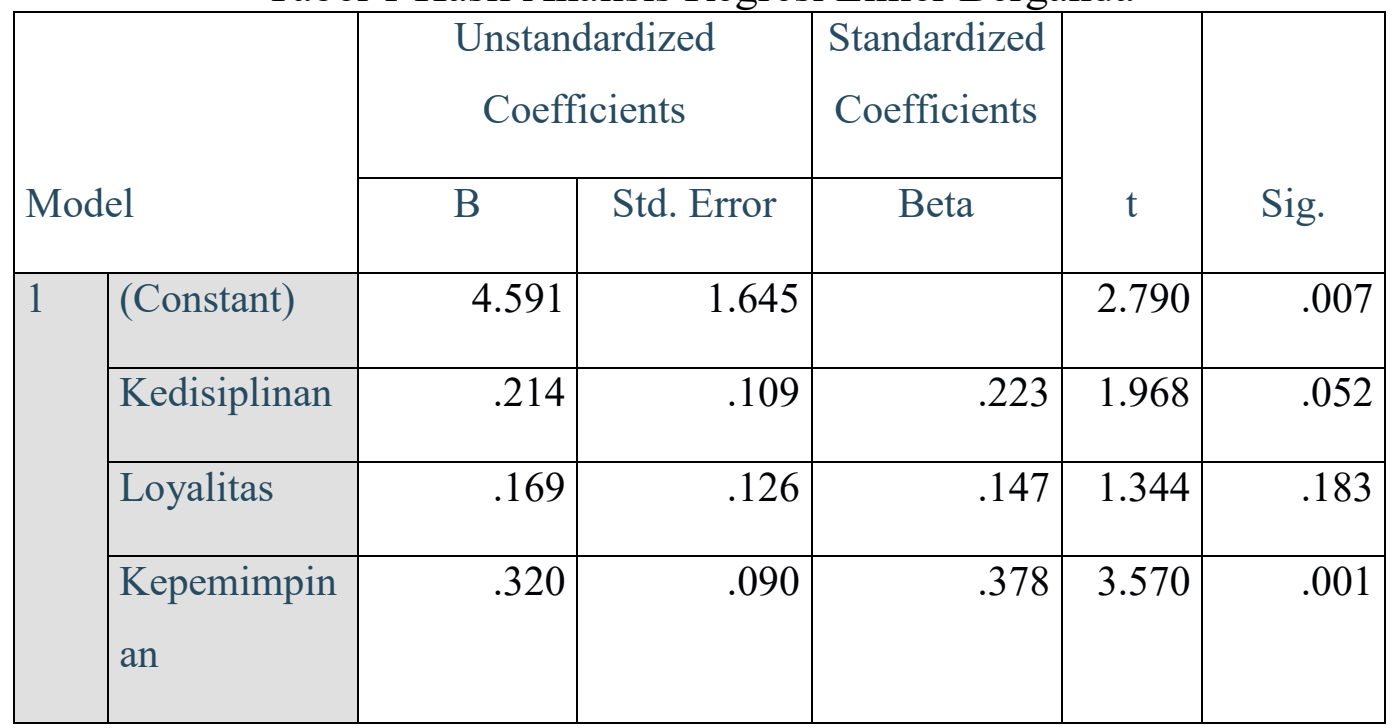

a. Dependent Variable: Produktivitas

model persamaan regresi yang dapat dituliskan dari hasil tersebut dalam bentuk persamaan regresi sebagai berikut :

$$
\mathrm{Y}=4,591+0,214 \mathrm{X} 1+0,169 \mathrm{X} 2+0,320 \mathrm{X} 3
$$

persamaan regresi tersebut dapat dejelaskan sebagai berikut :

a. konstanta sebesar 4,591 memiliki arti jika variabel X1, X2 dan X3 tidak terdapat perubahan maka nilai produktivitas pegawai Sekretariat Dewan Perwakilan Rakyat Daerah Kabupaten Kepulauan Selayar adalah sebesar 4,591; 


\section{AkMen \\ Volume 17 Nomor 3 September 2020 \\ Hal. 427 - 437 \\ e-ISSN : 2621-4377 \& p-ISSN : 1829-8524 \\ Homepage: https//e-jurnal.stienobel-indonesiaacid/index.php/akmen}

b. koefisien regresi variabel kedisiplinan mempunyai arah positif dalam pengaruhnya terhada produktivitas. Nilai koefisien sebesar 0,214 mengindikasikan bahwa jika terjadi peningkatan senilai satu satuan dalam variabel $\mathrm{X} 1$ dan variabel lain bersifat tetap maka $\mathrm{Y}$ atau produktivitas Pegawai Kantor Sekretariat Dewan Perwakilan Rakyat Daerah akan bertambah sebesar 0,214 ;

c. koefisien regresi variabel Loyalitas mempunyai arah positif dalam pengaruhnya terhadap Produktivitas pegawai Sekretariat Dewan Perwakilan Rakyat Daerah Kabupaten Kepulauan Selayar Nilai koefisien sebesar 0,169 mengindikasikan bahwa jika terjadi peningkatan senilai satu satuan dalam variabel X2 dan variabel lain bersifat tetap maka Y atau Produktivitas Pegawai Kantor Sekretariat Dewan Perwakilan Rakyat Daerah Kabupaten kepulauan Selayar akan bertambah sebesar 0,169 ;

d. koefisien regresi variabel Kepemimpinan mempunyai arah positif dalam pengaruhnya terhadap Produktivitas pegawai Kantor Sekretariat Dewan Perwakilan Rakyat Daerah Kabupaten Kepulauan Selayar Nilai koefisien sebesar 0,320 mengindikasikan bahwa jika terjadi peningkatan senilai satu satuan dalam variabel X3 dan variabel yang lain bersifat tetap maka Y atau Produktivitas pegawai Kantor Sekretariat Dewan Perwakilan rakyat Daerah Kabupaten Kepulauan Selayar akan bertambah sebesar 0,320.

\section{Pengujian hipotesis secara parsial}

\section{Variabel Kedisiplinan}

Hasil pengujian diperoleh nilai $\mathrm{t}$ untuk variabel kedisiplinan menunjukkan nilai $\mathrm{t}=1,968$ sedangkan nilai $\mathrm{t}$ tabel untuk $\mathrm{n} 88$ adalah sebesar 1,987 dengan demikian tidak terdapat pengaruh antara kedisiplinan terhadap produktivitas. Dengan nilai signifikansi sebesar 0,052 maka $0,052>0,05$. Tidak berpengaruh signifikan terhadap produktivitas kerja. Catatan Khusus hasil uji $\mathrm{t}$ maupun uji signifikansi terdapat perbedaan yang sangat tipis dan apabila angka hasil tersebut dibulatkan maka hasil pembulatan akan sama persis dengan standar baik untuk uji t maupun untuk uji signifikansi sehingga dengan demikian kedisiplinan tetap perlu untuk diperhatikan sebagai variabel yang dapat mempengaruhi Produktuvitas kerja.

\section{Variabel Loyalitas}

Hasil pengujian diperoleh nilai $t$ untuk variabel Loyalitas menunjukkan nilai $\mathrm{t}=1,344$ sedangkan nilai $\mathrm{t}$ tabel untuk $\mathrm{n} 88$ adalah sebesar 1,987 dengan demikian nilai t hitung lebih kecil dari nilai t tabel sehingga terbukti bahwa tidak terdapat pengaruh antara variabel loyalitas dengan produktivitas Pegawai Kantor Sekretariat Dewan Perwakilan Rakyat Daerah Kabupaten Kepulauan Selayar dengan nilai signifikansi sebesar 0,183 >0,05. Dengan nilai signifikansi di atas 0,05 tersebut menunjukkan bahwa loyalitas tidak memiliki pengaruh terhadap produktivitas kerja pegawai pada kantor sekretariat Dewan Perwakilan Rakyat Daerah Kabupaten Kepulauan Selayar. Hal ini berarti Hipotesis 2 ditolak. Arah koefisien regresi positif berarti bahwa Loyalitas memiliki pengaruh positif namun tidak signifikan terhadap Produktivitas. 


\section{Variabel Kepemimpinan}

Hasil pengujian diperoleh nilai t untuk variabel Kepemimpinan menunjukkan nilai $\mathrm{t}=3,570$ sedangkan nilai $\mathrm{t}$ tabel untuk $\mathrm{n} 88$ adalah sebesar 1,987 dengan demikian nilai t hitung lebih besar dari nilai t tabel sehingga terbukti bahwa terdapat pengaruh antara variabel kepemimpinan dengan produktivitas Pegawai Kantor Sekretariat Dewan Perwakilan Rakyat Daerah dengan nilai signifikansi sebesar 0,001 $<0,05$. Dengan nilai signifikansi di bawah 0,05 tersebut menunjukkan bahwa kepemimpinan memiliki pengaruh yang signifikan terhadap produktivitas Pegawai Kantor Sekretariat Daerah Kabupaten Kepulauan Selayar. Hal ini berarti Hipotesis 3 diterima. Arah koefisien regresi positif berarti bahwa Kepemimpinan memiliki pengaruh positif yang signifikan terhadap Produktivitas. Semakin baik sifat kepemimpinan yang dimiliki oleh pegawai akan semakin meningkatkan produktivitas yang dapat dicapainya, dan jika jika terjadi penurunan sifat kepemimpinan maka akan berpengaruh menurunkan produktivitas yang akan dicapainya.

\section{Uji F (Pengujian Hipotesisi Secara Simultan)}

Uji F dimaksudkan untuk mengetahui apakah variabel independent dalam hal ini adalah variable kedisiplinan, variabel loyalitas dan variabel kepemimpinan berpengaruh secara bersama sama terhadap produktivitas Pegawai Kantor Sekretarian Daerah Kabupaten Kepulauan Selayar .Hasil perhitungan uji F untuk menguji hubungan variabel indpenden secara bersama-sama diperoleh pada Tabel 2 berikut ini :

Tabel 2 Tabel ANOVA Pengujian Pengaruh Secara Bersama-sama

\begin{tabular}{|l|l|r|r|r|r|r|}
\hline \multicolumn{7}{|c|}{ ANOVA $^{\mid 2}$} \\
\hline \multicolumn{2}{|l|}{ Model } & Sum of Squares & df & Mean Square & F & Sig. \\
\hline 1 & Regression & 135.925 & 3 & 45.308 & 19.119 & $.000^{\mathrm{b}}$ \\
\cline { 2 - 8 } & Residual & 199.064 & 84 & 2.370 & & \\
\cline { 2 - 8 } & Total & 334.989 & 87 & & & \\
\hline
\end{tabular}

a. Dependent Variable: Produktivitas

b. Predictors: (Constant), Kepemimpinan, Loyalitas, Kedisiplinan

dari hasil pengolahan statistik di atas menunjukkan nilai $\mathrm{F}$ hitung $=19,119$ sedangkan $\mathrm{F}$ tabel untuk $\mathrm{n} 88$ dengan $\mathrm{df} 1=\mathrm{k}-1=2$ dimana $\mathrm{k}$ adalah jumlah seluruh variabel (3variabel) dikurang dengan variabel dependent ( 1 variabel) dan df $2=$ $\mathrm{n}-\mathrm{k}=85$ dimana $\mathrm{n}$ adalah sebanyak 88 dikurang dengan $\mathrm{k}$ (3) adalah pada titik nilai $F$ tabel sebesar 3,10 hasil ini menunjukkan nilai $F$ hitung lebih besar dari nilai $\mathrm{F}$ table untuk itu dapat disimpulkan bahwa terdapat pengaruh antara variabel-variabel X secara bersama-sama terhadap variabel Y (produktifitas).

Nilai signifikansi sebesar 0,000 $<0,05$. Dengan nilai signifikansi di bawah 
0,05 menunjukkan bahwa secara bersama-sama Kedisiplinan dan Loyalitas serta Kepemimpinan mempunyai pengaruh yang positif dan signifikan terhadap Produktivitas Pegawai Kantor Sekretariat Dewan Perwakilan Rakyat Daerah Kabupaten Kepulauan Selayar.

\section{Variabel Paling Dominan}

Penelitian ini menunjukkan bahwa variabel kepemimpinan merupakan variabel yang paling dominan mempengaruhi produktivitas Pegawai Kantor Sekretariat Dewan Perwakilan Rakyat Daerah Kabupaten Kepulauan Selayar. Variabel kepemimpinan mencapai nilai b sebesar 0,320 lebih tinggi dibanding pencapaian nilai b untuk dua variabel lainnya yaitu variabel kedisiplinan yang hanya mencapai nilai b sebesar 0,214 dan variabel loyalitas yang hanya mencapai nilai b sebesar 0,169 .

\section{Koefisien Determinasi}

Koefisien determinasi ini digunakan untuk mengetahui seberapa besar pengaruh variabel-variabel bebas memiliki pengaruh terhadap variabel terikatnya. Nilai koefisien determinasi ditentukan dengan nilai $R$ square.

Tabel 3 Koefisien Determinasi

\begin{tabular}{|l|c|r|c|}
\hline Model & R & R Square & $\begin{array}{c}\text { Adjusted R } \\
\text { Square }\end{array}$ \\
\hline 1 & $.637^{\mathrm{a}}$ & .406 & .385 \\
\hline
\end{tabular}

a. Predictors: (Constant), Kedisiplinan, Loyalitas, Kepemimpinan

Hasil perhitungan regresi dapat diketahui bahwa koefisien determinasi $R$ Square yang diperoleh sebesar 0,406. Hal ini berarti 40,6\% produktivitas Pegawai pada Kantor Sekretariat Dewan Perwakilan Rakyat Daerah Kabupaten Kepulauan Selayar dipengaruhi oleh Kedisiplinan, Loyalitas dan Kepemimpinan sedangkan sisanya yaitu 59,4\% Produktivitas Pegawai Kantor Sekretariat Dewan Perwakilan Rakyat Daerah Kabupaten Kepulauan Selayar dipengaruhi oleh variabel-variabel lainnya yang tidak diteliti dalam penelitian ini.

\section{Pembahasan}

\section{Pengaruh Kedisiplinan Terhadap Produktivitas}

Secara teoritik dan berbagai fakta empiris menunjukan bahwa kedisiplinan memiliki pengaruh yang kuat terhadap produktivitas hal ini dapat dijelaskan dengan fakta bahwa seseorang yang memiliki disiplin yang tinggi maka ia akan memiliki produktivitas yang tinggi pula, seseorang yang memiliki prinsip disiplin maka ia akan melaksanakan segala sesuatunya sesuai dengan ketentuan yang berlaku menempatkan sesuatu pada tempatnya dan mengikuti seluruh prasyarat yang dibutuhkan dalam melaksanakan suatu pekerjaan dengan demikian sikap disiplin akan mengantarkan seseorang pada tindakan yang menuju pada terciptanya suatu keberhasilan sesuai dengan yang diharapkan.

Dari hasil koefisien regresi penelitian ini menunjukkan bahwa kedisiplinan 
memiliki arah hubungan yang postif terhadap produktivitas kerja pegawai pada Kantor Sekretariat Daerah kabupaten Kepulauan Selayar meskipun hasil penelitian ini menunjukkan hasil yang samar dengan selisih yag sangat tipis antara $t$ tabel dengan $t$ hitung yang dihasikan dalam penelitian hal ini juga dibuktikan dengan nilai signifikansi dengan nilai selisih yang tipis yaitu 0,052 sedangkan nilai tingkat alfa adalah 0,05 . Namun koefisien regresi tetap menunjukkan bahwa bahwa kedisiplinan memiliki arah hubungan yang positif terhadap terhadap produktivitas.

Penelitian terdahulu yang membuktikan bahwa kedisiplinan terutama disiplin waktu tidak berpengaruh terhadap peningkatan produktivitas juga ditunjukkan oleh hasil penelitian yang dilakukan oleh Khaslinawati (2016) yang membuktikan bahwa kedisiplinan waktu tidak berpengaruh signifikan terhadap produktivitas hasil ini menunjukan bahwa dalam obyek tetentu kedisiplinan bisa tidak berpengaruh terhadap produktivitas.

\section{Pengaruh Loyalitas Terhadap Produktivitas}

Penelitian ini menunjukan bahwa tidak terdapat pengaruh antara loyalitas dengan produktivitas kerja hal ini tak dapat dipungkiri bertentangan dengan apa yang seharusnya, secara teori loyalitas akan berpengaruh terhadap produktivitas penelitian terdahulu yang dilakukan oleh (Syaputra dkk., 2017) juga membuktikan bahwa loyalitas berpengaruh terhadap produktivitas dengan demikian hasil penelitian ini tidak sejalan dengan penelitian yang dilakukan oleh Syahputra.

Beberapa penjelasan terkait dengan hal tersebut dapat penulis sampikan berdasarkan hasil observasi pada Kantor Sekretariat Dewan Perwakilan Rakyat Daerah Kabupaten kepulauan Selayar sebagai berikut: Pekerjaan kesekretariatan pada dasarnya adalah permasalahan pelayanan kepada anggota dewan dengan cara mendukung tertib administrasi yang dibutuhkan oleh anggota dewan pengaturan jadwal serta permasalahan operasional anggota dewan lainnya pekerjaan tersebut terkadang menuntut jam kerja ekstra sehingga pegawai terkadang lembur di luar jam kerja yang resmi permasalahan lain adalah karena keseketariatan adalah pelayanan kepada anggota dewan maka tugas kesekretariatan sering melibatkan perasaan sebagai pelayan person dengan demikian ketika permasalahan loyalitas dipertanyakan dalam penelitian ini maka mendapatkan tanggapan yang beragam yang sangat dimungkinkan berbeda dengan ketika responden mengisi kuisioner tentang variabel independen yang lain yaitu kedisiplinan dan kepemimpinan.

Penelitian ini juga melibatkan tenaga kerja honorer yang sudah mengabdi dalam jangka waktu yang lama sehingga ketika pertanyaan loyalitas dipertanyakan melalui kuisioner dalam penelitian ini maka akan menimbulkan persaaan serta tanggapan lain terkait dengan loyalitas dan status kerja dari responden yang bersangkutan.

\section{Pengaruh Kepemimpinan Terhadap Produktivitas}

Penelitian ini membuktikan bahwa terdapat pengaruh yang positif dan signifikan antara kepemimpinan dengan produktivitas hasil ini sesuai dengan teori-teori kepemimpinan yang menyebutkan bahwa keberhasilan organisasi akan sangat dipengaruhi oleh kepemimpinan yang dikembangkan begitupula dengan sifat-sifat kepemimpinan yang dimiliki oleh individu-individu yang ada di dalam organisasi, organisasi yang memiliki anggota dengan sifat kepemimpinan yang tinggi akan menjadi modal yang kuat bagi organisasi dalam mencapai visi dan misi yang diembannya. Dan 
bagi individu-individu yang memiliki sifat kepemimpinan yang baik akan lebih mudah dalam menjalankan setiap tugas dan kewajiban yang diembannya dan hal tersebut secara langsung maupun tidak langsung akan mempengaruhi produktivitas bagi pegawai yang bersangkutan.

Hasil penelitian ini juga sejalan dengan hasil penelitian yang dilakukan oleh (Haenisch, 2012)yang membuktkan bahwa factor kepemimpinan memiliki pengaruh terhadap produktivitas pegawai.

Penelitian ini menganalisa sifat-sifat kepemimpinan yang dimiliki oleh individuindividu yang pegawai pada Kantor Sekretariat Dewan Perwakilan Rakyat Daerah yang kemudian dikaitkan dengan produktivitas yang dimiliki oleh pegawai tersebut dengan demikian kepemimpinan yang dijadikan sebagai variabel dalam penelitian ini bukanlah kepemimpinan yang dinilai oleh responden terhadap atasannya.

Pendekatan dalam penelitian ini tentang sifat kepemimpinan individu ini menjadi pendekatan yang lebih realistis terkait dengan tujuan penelitian yaitu sejauhmana sifat kepemimpinan yang dimiliki responden dan bagiman sifat tersebut mempengaruhi produktivitasnya sehingga hasilnya akan lebih komprehensif memberikan informasi bagi organisasi dalam rangka kebutuhan untuk mengembangkan pegawai yang dimilikinya.

Pemilihan sifat kepemimpinan individu dalam penelitan ini merujuk pada berkembangnya Ilmu pengetahuan dan hasil-hasil penelitian berkaitan dengan kepemimpinan maka konsep kepemimpinan menjadi berubah dan merambah pada paradigm yang lebih luas jika dalam konsep tradisional kepemimpinan hanya berfokus pada diri seorang pemimpin atau kepemimpinan yang dikembangkan oleh organisasi dalam kontek hirarkhi seorang pemimpin dalam struktur organisasi, maka kepemimpinan dalam paradigm baru adalah melingkupi semua individu yang bergerak untuk mencapai tujuan terntentu termasuk individu yang ada dalam organisasi meskipun ia bukan seorang pemimpin tetapi kepemilikkan sifat kepemimpinan sangat dibutuhkan oleh organisasi dari setiap individu yang ada di dalamnya (Arsenault, 2003). Dalam kontek ini banyak sekali organisasi yang memasukan unsur kepemimpinan (leadership) sebagai bagian dari form assessment kepada seluruh pegawai yang ada di dalam organisasi.

\section{Pengaruh Antara Kedisiplinan, Loyalitas dan Kepemimpinan Terhadap Produktivitas}

Sebagaimana telah dijelaskan secara parsial melalui pembahasan pengaruh antara variabel kedisiplinan, loyalitas dan kepemimpinan terhadap produktivitas di atas maka secara teoritis ketiga variabel independen tersebut memiliki pengaruh terhadap Produktivitas, sehinga dengan demikian kedisiplinan dalam organisasi menjadi salah satu konsentrasi manajemen untuk bagaimana cara mnerapkan dan menegakkannya demikian juga loyaitas, organisasi memiliki kepentingan yang sangat besar untuk dapat memiliki pegawai yang memiliki loyalitas, begitupula dengan kepemimpinan hampir semua pakar manajemen menyatakan bahwa keberhasilan organisasi sangat dipengaruhi oleh kepemimpinan yang dikembangkan oleh organisasi tersebut baik dipandang dari manajemen selaku regulator maupun kepemimpinan individu yang sangat penting agar organisasi dapat berjalan sesuai dengan yang diharapkan. Melalui pemikiran tersebut maka sangat jelas jika kedisiplinan, loyalitas dan kepemimpinan secara bersama-sama akan berpengaruh terhadap tingkat produktivitas kerja fakta tersebut sejalan dengan hasil penelitian ini yang membuktikan bahwa kedisiplinan, loyalitas dan kepemimpinan berpengaruh positif dan signifikan secara simultan terhadap produktivitas pegawai 
Kantor Sekretariat daerah Kabupaten kepulauan Selayar.

\section{KESIMPULAN}

Berdasarkan hasil penelitian serta pembahasan yang telah disampaikan sebelumnya maka dapat ditarik kesimpulan bahwa hasil koefisien regesi Penelitian ini menunjukkan arah hubungan yang positif tetapi tidak berpengaruh secara signifikan antara kedisiplinan terhadap produktivitas pegawai, begitupula untuk loyalitas hasil koefisien regresi menunjukkan arah hubungan yang positif tetapi tidak berpengaruh signifikan antara loyalitas terhadap produktivitas, terdapat pengaruh yang positif dan signifikan antara kepemimpinan terhadap produktivitas pegawai Kantor Sekretariat Dewan Perwakilan Rakyat Daerah Kabupaten Kepulauan Selayar. Terdapat pengaruh yang positif dan signifikan secara simultan antara kedisiplinan, loyalitas dan kepemimpinan terhadap kinerja pegawai kantor Sekretariat Dewan Perwakilan Rakyat Daerah Kabupaten Kepualauan Selayar. Kepemimpinan merupakan variabel yang berpengaruh dominan terhadap produktivitas kerja pegawai kantor Sekretariat Dewan Perwakilan Rakyat Daerah Kabupaten Kepulauan Selayar.

\section{DAFTAR PUSTAKA}

Arsenault, P. (2003). Leadership assessment and development. Improving leadership in nonprofit organizations, 252-266.

Ghozali, Imam. 2005. Aplikasi Analisis Multivariate dengan Program SPSS. Badan Penerbit Universitas Diponegoro. Semarang.

Haenisch, J. P. (2012). SAGE Open.

Hidayat, M., \& Latief, F. (2018). THE INFLUENCE OF DEVELOPING HUMAN CAPITAL MANAGEMENT TOWARD COMPANY PERFORMANCE (THE EVIDENCE FROM DEVELOPER COMPANIES IN SOUTH SULAWESI INDONESIA). SEIKO: Journal of Management \& Business, 2(1), 11-30.

Paul M. Arsenault (2020) Leadership Assesment And Development. Recommendation For New Assesment Model. West Chester University Of Pennsylvania.

Pusat Bahasa Departemen Pendidikan Nasional.2002, Kamus Besar Bahasa Indonesia. Edisi ke-3, Jakarta: Balai Pustaka.

Rivai, V. (2004). Manajemen sumber daya manusia utnuk perusahaan: Dari teori ke praktik. PT RajaGrafindo Persada.

Syaputra, A., Wasnury, R., \& Rama, R. (2017). Pengaruh Loyalitas Kerja Dan Pelatihan 


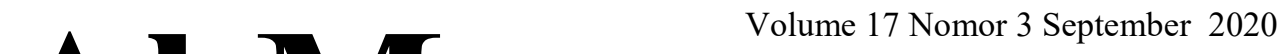 Hal. 427 - 437 \\ e-ISSN : 2621-4377 \& p-ISSN : 1829-8524 \\ Homepage: https//e-jurnal.stienobel-indonesia.acid/index.php/akmen}

Kerja Terhadap Peningkatan Produktivitas Kerja Karyawan Pada Perusahaan Daerah Air Minum (Pdam) Tirta Siak Kota Pekanbaru. 